\title{
Agostinho: A FÉ TEM OLHOS PRÓPRIOS ${ }^{1}$
}

\author{
Silvia Maria Contaldo ${ }^{23}$
}

Resumo: Trata-se de um comentário ao texto de santo Agostinho intitulado De fide rerum quae non videntur, na verdade, um sermão motivado pelos equívocos ou mesmo os enganos daqueles que não professavam a fé cristá. Provavelmente o texto foi escrito entre 420-425, tempo propício para fortalecer a fé nas coisas invisíveis, tendo em vista o horizonte que anunciava o declínio do Império Romano. $\mathrm{Na}$ composição do texto, em consonância com o estilo próprio de um sermão, são oito breves partes. Sem perder a coesão em torno do tema principal, Agostinho pode concluir que a fé tem olhos próprios capazes de ver - e de nos permitir crer - nas coisas invisíveis.

Palavras-chave: Santo Agostinho. Fé. Sermão. Religião cristã. Visão interior.

Nunca será demasiado dedicar-se à compreensão do pensamento de Agostinho. Nunca será demais enfatizar a riqueza e originalidade do conjunto da obra agostiniana, constituída por tratados, cartas, sermões, diálogos filosóficos, comentários, num exercício incansável de interessantíssimas interrogaçóes. Jaspers já dissera que Agostinho pensa perguntando. E, nesses tempos de nebulosidades e cegueiras propositais nos quais as perguntas são muitas e as respostas, proporcionalmente, são cada vez difíceis, vale retomar um texto de Agostinho - De fide rerum quae non videntur - que nos instiga

${ }^{1}$ Texto apresentado no $3^{\circ}$ Ciclo de Conferências Agostinianas, em 2013, no Mosteiro de São Bento, Sáo Paulo.

2 Professora de Filosofia Medieval na Pontifícia Universidade Católica de Minas Gerais (PUC Minas), Belo Horizonte, MG - Brasil. (D) https://orcid.org/0000-0001-5214-8611 E-mail: silviacontaldo@ hotmail.com

Doutora em Filosofia pela Pontifícia Universidade Católica do Rio Grande do Sul (UFRGS). Membro do GT/Anpof Agostinho de Hipona e o Pensamento Tardo-antigo.

3 Professora de Filosofia da Educação na Faculdade Jesuíta de Filosofia e Teologia (FAJE), Belo Horizonte, MG - Brasil.

http://dx.doi.org/10.1590/0101-3173.2019.v42esp.07.p115

This is an open-access article distributed under the terms of the Creative Commons Attribution License. 
a um proceder mais reflexivo e à certa atenção ao que não se vê, graças ao movimento da fé nas coisas invisíveis. ${ }^{4}$

Fé. Vocábulo monossilábico, mas de uma força semântica e simbólica sem precedentes. Palavra que se presta a incontáveis usos, desde as experiências mais banais da vida cotidiana - eu tenho 'fé' que meu ônibus não vai atrasar, tenho 'fé' que ainda ganho na loteria -, passando por aquelas situaçóes-limites, que escapam à racionalidade, em que todos depositamos uma 'fé' - tenho fé que ele vai se curar. Também naqueles momentos de reflexão, de volta a si mesmo, de desconcerto frente a um mundo dado como pronto, é esse pequeníssimo vocábulo que nos auxilia. Tenho fé! Um dia as coisas melhoram.

Fé. Então, como defini-la? E, definindo-a, como explicá-la a outrem? É preciso dar provas de nossa fé? Se eu não vejo eu não creio? São questóes dessa natureza e com muita agudeza de espírito que estáo postas nesse texto de Agostinho 5 que, com a devida vênia ao autor, intitulei $A$ fé tem olhos próprios para comentário que se segue.

Justifico minha escolha por esse título. Trata-se de uma expressão que Agostinho usou em carta dirigida a Consêncio ${ }^{6}$. Nessa epístola Agostinho trata de responder ao monge espanhol questóes sobre o tema da Trindade, náo sem antes propor-lhe certa metodologia de leitura. Por exemplo, Agostinho ensina-lhe uma regra básica, universal e sem data de validade: "Assinale as passagens que não lhe parecem claras e venha ter comigo e assim você poderá perguntar sobre todas as questóes que são do seu interesse." (Carta 120, I, 1). ${ }^{7}$ Melhor procedimento pedagógico não há. Aliás, são desses pontos obscuros,

${ }^{4}$ A fé nas coisas invisiveis. Assim foi traduzido, recentemente, para a língua portuguesa. No latim, De fide rerum quae non videntur. Como entre a tradução portuguesa e a versão latina há sensíveis diferenças, optei por copiar em nota de rodapé - para cada citação - o texto latino, para que não se perca a riqueza da literariedade agostiniana. No corpo do texto a indicação da citação refere-se à edição da Paulus, de 2017 e, no rodapé, estão as mesmas citaçôes da edição da BAC, 1948.

$5 \mathrm{O}$ texto De fide rerum quae non videntur é, provavelmente, um sermão proferido por Agostinho com o objetivo de refutar certas incredulidades e afirmar a indispensabilidade da fé para os arranjos existenciais. Sem a fé, diz Agostinho, não existiria amizade, nem amor entre familiares, nem relaçôes sociais. É preciso, afirma Agostinho, ter fé em muitas coisas ainda que não as vejamos. (RODRIGUEZ, H. Introduccion, p. 791-92).

${ }^{6}$ Epistola 120. Disponível em: https://www.augustinus.it/latino/lettere/index2.htm

7 Proinde volui ut quaedam nostra opuscula, quae arbitratus sum tibi esse necessaria, non procul a nobis positus, sed potius apud nos legeres, ut ea quae forte minus intellexisses, non difficulter praesens interrogares, atque ex nostra sermocinatione mutuoque colloquio, quantum Dominus et nobis promere, et tibi capere tribuisset, quid in libris tuis emendandum esset, ipse cognosceres, ipse emendares. (Ep. 120, I, I). 
pouco claros detectados nas lectiones dos mestres medievais que nasceram as quaestiones, condição essencial de pesquisa e atividade filosóficas. Desse modo, ao discorrer sobre o tema específico que lhe fora demandado, o tema da fé emerge, como não poderia deixar de ser. Em certa altura do texto, enfatizando o quão importante é a inteligência da fé, Agostinho afirma que "é melhor crer no que é verdadeiro, ainda que não possa ser visto, do que pensar que aquilo que vemos é verdadeiro quando é falso. Também a fé tem olhos próprios com os quais de algum modo vê que é verdadeiro o que ainda não vê, e com os quais vê, com toda certeza, que ainda náo vê aquilo em que crê." (Carta 120, II, 8 , grifo nosso).$^{8}$

Será esse então o nosso ponto de partida para o comentário sobre esse sermão intitulado originariamente Sobre a fé nas coisas que não veem ou sobre como descobrir que a fé tem olhos próprios e, com eles, aprender a ver com mais acuidade e profundidade.

Antes, porém, vale um esclarecimento sobre a função educadora do sermão. Muitos entendem a palavra 'sermão' como algo cansativo, às vezes moralizante como costumamos escutar na linguagem coloquial: 'lá vem meu pai com o sermão', 'nossa, o professor hoje deu um sermão na gente'.

No entanto, naqueles tempos de Agostinho, o sermão tinha função diversa e específica. Dirigido ao povo, muitas vezes era complemento - uma espécie de nota de rodapé - para as liturgias. Sabemos que as notas de rodapé esclarecem e engrandecem sobremaneira o texto. Guardadas as proporçóes, essa era a natureza do sermão proferido pelo bispo. Os ouvintes ficavam de pé e um sermão não tinha duração temporal prefixada. As palmas dos ouvintes, ao longo do sermão, demonstravam seu entendimento e sua concordância com o que se escutava, o que ainda hoje continuamos a fazer, para manifestar nossa satisfação, júbilo ou alegria com discursos, conferências etc. Agostinho utilizou inúmeras vezes esse recurso em suas liturgias, pois tratava-se de tornar o mais claro possível a mensagem cristã e sua implicação e aplicação na vida

\footnotetext{
${ }^{8}$ Falsae itaque rationi, non solum ratio vera, qua id quod credimus intellegimus, verum etiam fides ipsa rerum nondum intellectarum sine dubio praeferenda est. Melius est enim quamvis nondum visum, credere quod verum est, quam putare te verum videre quod falsum est. Habet namque fides oculos suos, quibus quodammodo videt verum esse quod nondum videt, et quibus certissime videt, nondum se videre quod credit. Porro autem qui vera ratione iam quod tantummodo credebat intellegit, profecto praeponendus est ei qui cupit adhuc intellegere quod credit; si autem nec cupit, et ea quae intellegenda sunt, credenda tantummodo existimat, cui rei fides prosit ignorat: nam pia fides sine spe et sine caritate esse non vult. Sic igitur homo fidelis debet credere quod nondum videt, ut visionem et speret et amet. (Ep. 120, II, 8).
} 
prática. E Agostinho demonstrava saber a exata dimensão pedagógica desse tipo de pregação. Por exemplo, quando o assunto demandava mais tempo, ele pedia 'um pouco mais de paciência' (LAUAND, 1998). Dirigindo-se a todos, indistintamente, os sermóes mergulhavam na vida cotidiana, no universo do vivido e da vivência, de modo a fazer sentido para o ouvinte. Mais ainda, para Agostinho, o sermão precisava dar conta dessa vinculação entre discurso religioso e vida prática, entre a palavra falada e a açáo concretizada, em consonância com a leitura da vida.

Desse modo, muitas vezes Agostinho mostrava-se mais pastor do que retórico, embora o antigo professor de retórica nunca tenha sido descuidado com o exercício da palavra. E por isso mesmo, como bom pregador e educador, em muitos dos seus sermóes rememora, faz associaçôes, busca exemplos, volta aos temas já tratados. No processo educativo, nunca é demais repetir, no bom sentido que essa palavra carrega. Quantas e quantas vezes pais e mães repetem ensinamentos! $\mathrm{E}$ assim como nossos pais se apoiam nas tradiçóes, nos valores que lhe foram passados e, por conta deles, nos advertem, também Agostinho se apoiava nos textos sagrados para repetir ensinamentos, reiterar condutas, enfatizar hábitios, admoestar. Do farto material desses textos, Agostinho retirava exemplos, fazia conexóes, buscava reprimendas, de maneira que sua fala e propósito sermonais ficassem cristãmente fundamentados.

É sob esse enfoque que retomamos aqui o sermão agostiniano sobre o tema da fé nas coisas que não veem para, quem sabe, ampliar nosso horizonte de visibilidades. É bom lembrar que, no amplo repertório da literatura universal, o tema da fé nas 'coisas que não veem' tem sido ingrediente vital para tramas, dramas, histórias de amor e de dor. Beatriz, por exemplo, dirá a Dante: "Não pense que o paraíso esteja apenas nos meus olhos." Além do que vemos, do que nos aparece, dos simulacros, há ainda muito território não visível para ser conhecido. Aliás, esse tem sido o escopo da filosofia desde os antigos gregos.

Deve-se ressaltar também que o sermão em pauta já teve sua paternidade questionada. Hoje não mais. Foi escrito provavelmente entre 420-425. É texto de um Agostinho maduro, bispo e pastor incansável, partícipe das agruras do seu tempo. Sabia, portanto, lidar bastante bem com temas que, ora mais ora menos espinhosos, marcariam seu lugar no universo filosófico da Patrística.

Para dirimir essa dúvida autoral basta retomar uma carta de Agostinho, a Epístola 231, redigida em 429, em resposta ao conde Dario, para quem

\footnotetext{
${ }^{9}$ Cf. A divina comédia. Paraíso, canto XVIII.
} 
Agostinho anteriormente escrevera um bilhete. Com a resposta de Dario, Agostinho lhe escreve mais demoradamente ${ }^{10}$. Como se pode constatar, entre a redação do sermão e o envio da carta passaram-se alguns anos. Impressiona, nessa carta, o tom gentil e receptivo do velho Agostinho a alguém certamente mais novo - a quem ele chama de 'cristão na caridade cristã' e oferece suas Confissöes $^{11}$. O interessante é que, ao finalizar a carta, Agostinho escreveu que enviara também outros livros que não haviam sido pedidos, mas, ele, Agostinho, não se contentara em atender apenas ao que havia sido solicitado. E, nessa encomenda, a princípio não demandada, estavam os textos Sobre a fé nas coisas que não veem, Sobre a paciência, Sobre a continência, Sobre a providência e um outro Sobre a fé, a esperança e a caridade. ${ }^{12} \mathrm{E}$ acrescenta ainda outro pedido. Se Dario conseguisse ler todos aqueles escritos enquanto estivesse na África, que lhe enviasse suas impressóes. Iria mesmo esperar pela resposta de Conde, pois essa correspondência epistolar lhe fazia bem ${ }^{13}$.

O sermão Sobre a fé nas coisas que não veem tem por epígrafe: "Crer no que não vemos não é para nós cristãos uma temeridade repreensível e

${ }^{10} \mathrm{O}$ conde Dario, católico, encontrava-se em uma missão de paz na África, numa tentativa de conciliação entre Bonifácio e corte imperial, conforme registra A. Trapé. Naquela ocasião, Agostinho lhe escreveu um bilhete "elogiando sua missão pacífica" e justificando sua impossibilidade de encontrálo pessoalmente: a saúde física e o duplo frio, do inverno e da idade". Dario lhe respondeu e, além de "lhe pedir uma cópia de Confissóes enviou-lhe remédio para cuidar da saúde e dinheiro para adquirir livros ou restaurar os da biblioteca" (TRAPÉ, 2019, p. 471-2).

${ }^{11}$ Quia igitur non potui verbis explicare quantam delectationem de tuis litteris ceperim, unde me delectaverint, dixi: iam quod nequivi satis dicere, id est, quantum delectaverint, tibi coniciendum relinquo. Sume itaque, mi fili, sume, vir bone et non in superficie, sed in christiana caritate christiane; sume, inquam, libros, quos desiderasti, Confessionum mearum: ibi me inspice, ne me laudes ultra quam sum; ibi non aliis de me crede, sed mihi; ibi me attende, et vide quid fuerim in meipso, per meipsum; et si quid in me tibi placuerit, lauda ibi mecum, quem laudari volui de me; neque enim me. (Ep. 231, 6).

${ }^{12}$ Misi et alios libros quos non petisti, ne hoc tantummodo facerem quod petisti; de Fide rerum quae non videntur, de Patientia, de Continentia, de Providentia, et unum grandem de Fide et Spe et Caritate. Hos omnes si dum es intra Africam legeris, iudicium tuum mitte de illis; aut mitte nobis, aut quo nobis a domino sene Aurelio mittatur, ibi dimitte: quamquam et ubicumque fueris speramus inde litteras tuas, et hinc tu, dum possumus, nostras Suscepi gratissime quae misisti; ubi et salutem meam quamvis corporalem, quoniam vis me utique sine impedimento malae valetudinis Deo vacare, et bibliothecam nostram, ut sint unde libri vel parentur vel reparentur, adiuvare dignatus es. Rependat tibi Dominus et hic et in futuro saeculo bona, quae talibus qualem te esse voluit, praeparavit14. Pignus pacis apud te depositum, nostrumque utrique dulcissimum, sicut ante a me salutari, ita nunc resalutari peto. (Ep. 231,7).

${ }^{13}$ Misi et alios libros quos non petisti, ne hoc tantummodo facerem quod petisti; de Fide rerum quae non videntur, de Patientia, de Continentia, de Providentia, et unum grandem de Fide et Spe et Caritate. Hos omnes si dum es intra Africam legeris, iudicium tuum mitte de illis; aut mitte nobis, aut quo nobis a domino sene Aurelio mittatur, ibi dimitte: quamquam et ubicumque fueris speramus inde litteras tuas, et hinc tu, dum possumus, nostras. Suscepi gratissime quae misisti. (Ep. 231, 7). 
sim fé digna de louvor." ${ }^{14}$ Vejamos então, o teor dessas palavras e sua força argumentativa para que nos limites do que for possível tenhamos, nós também, fé naquilo que não vemos.

O principal objetivo do sermão será demonstrar que a fé é indispensável em qualquer âmbito dos nossos arranjos existenciais, seja nas relaçóes particulares ou naquelas de maior amplitude social. E, seja qual for o sentido atribuído à fé, esse movimento de assentir, de dar crédito a algo ou a alguém, é ingrediente indispensável em nossas vidas.

Para cumprir esse objetivo, Agostinho dividiu o texto em oito breves capítulos. De cada um, procurar-se-á mostrar o que nos parece importante, lembrando que essas partes, em seu conjunto, visam demonstrar que acreditar naquilo que não vemos não é devaneio nem divagação. Acreditar e não se deixar cegar. Deslocar-se para além das aparências sensíveis. Fazer a travessia, afinal, rumo àquela margem que sabemos estar lá - embora não a vejamos, tal como o pintor francês René Magritte (1898-1967) retratou na sua tela Ponte de Heráclito ${ }^{15}$. A ponte está lá, embora seja possível ver apenas uma parte dela. Metade do caminho não se vê. Vemos no rio seu reflexo, por inteiro, mas não vemos por onde prosseguir, pelo menos à primeira vista. Agostinho, semelhante a Magritte, pintará as razões para crer naquilo que não vemos.

Em primeiro lugar Agostinho chama nossa atenção para a fé que depositamos no afeto dos amigos sem que possamos, de fato, ver esse afeto. Ele explica que "na vida social também se crê em muitas coisas sem que as vejamos. A boa vontade do amigo não se vê, porém se crê nela. Quer dizer, sem nenhuma fé sequer podemos ter certeza do afeto - do carinho - do amigo." (A fé nas coisas invisiveis, 1). ${ }^{16}$ É o que se constata na própria experiência, na vida cotidiana, que Agostinho póe em questão o assunto principal do seu sermão: "Para alguns a religião cristã é mais digna de chacota que de adesão

\footnotetext{
${ }^{14}$ In quo demonstratur nos in christiana religione, non culpabili temeritate, sed laudabili fide credere res quis oculis nostris non videmus. (De fide rerum quae non videntur, p. 794. Doravante: De fide rerum).

${ }^{15}$ A ponte de Heráclito (1935), óleo sobre tela, coleção particular.

${ }^{16}$ Sed dicis, ideo te credere amico, cuius videre cor non potes, quia in tuis tentationibus eum probasti, et cuiusmodi animum erga te haberet in tuis periculis, ubi te non deseruit, cognovisti. Numquid ergo, ut amicorum probetur erga nos caritas, videtur tibi nostra optanda calamitas? Nec quisquam erit ex amicis certissimis felix, nisi fuerit adversis rebus infelix: ut videlicet explorato alterius amore non fruatur, nisi suo dolore vel timore crucietur. Et quomodo in habendis veris amicis optari ea, non potius timeri, felicitas potest quam probare nisi infelicitas non potest? Et tamen verum est haberi posse amicum etiam in rebus prosperis, probari autem certius in rebus adversis." (De fide rerum, 1, 3).
} 
porque justamente náo apresenta diante de nossos olhos aquilo que podemos ver e, ao contrário, nos manda crer no que não veem." ${ }^{17}$ Sob essa perspectiva Agostinho procurará refutar aquelas pessoas que, presumidamente pensam ser sábias negando-se a crer naquilo que não veem. Cuidará de explicarlhes que é preciso crer em muitas coisas sem que possamos vê-las e que mesmo realidades suprassensíveis, nas quais cremos, não podem ser vistas pelos olhos corporais: "Nós, então, para confutar àqueles que consideram prudente náo querer crer no que náo pode ver, ainda que sejamos inaptos a mostrar aos olhos humanos a realidade divina na qual cremos, ainda assim mostramos à mente humana que se deve crer também nas coisas que não se veem." (A fé nas coisas invisiveis, 1$){ }^{18}$

Seria uma primeira advertência a esses insensatos ${ }^{19}$ - assim ele os denomina - que são tão escravos dos olhos do corpo que chegam a persuadirse de que náo devem crer no que náo se vê, ainda que eles mesmos creiam e conheçam muitas coisas que não se pode perceber com o sentido da visão. E são inumeráveis essas coisas de natureza invisível para os olhos sensitivos. Por exemplo, pergunta Agostinho:

A própria fé com a qual cremos, ou o pensamento com o qual sabemos crer ou não crer em alguma coisa, não têm relação alguma com a visão desses olhos carnais. O que pode ser táo óbvio, tão evidente, táo seguro à visão interior do espírito? Como, então, não se deve crer naquilo que não podemos ver com os olhos do corpo, quando vemos, sem dúvida alguma, impedidos de usar os olhos do corpo, que cremos ou não cremos?" ( $A$ fé nas coisas invisiveis, 1$).^{20}$

\footnotetext{
${ }^{17}$ Sunt qui putant christianam religionem propterea ridendam potius quam tenendam, quia in ea, non res quae videatur ostenditur, sed fides rerum quae non videntur, hominibus imperatur. Nos ergo ad hos refellendos, qui prudenter sibi videntur nolle credere, quod videre non possunt, etsi non valemus humanis aspectibus monstrare divina quae credimus tamen humanis mentibus etiam illa quae non videntur credenda esse monstramus. (De fide rerum, 1, 1).

${ }^{18}$ Nos ergo ad hos refellendos, qui prudenter sibi videntur nolle credere, quod videre non possunt, etsi non valemus humanis aspectibus monstrare divina quae credimus tamen humanis mentibus etiam illa quae non videntur credenda esse monstramus. (De fide rerum, 1, 1).

${ }^{19}$ Ac primum isti, quos oculis carneis sic stultitia fecit obnoxios, ut quod per eos non cernunt, non sibi existiment esse credendum, admonendi sunt quam multa non solum credant, verum etiam sciant, quae talibus oculis videri non possunt. (De fide rerum, 1,1 ).

${ }^{20}$ Quae cum sint innumerabilia in ipso animo nostro, cuius invisibilis est natura, ut alia taceam, fides ipsa qua credimus, sive cogitatio qua nos vel credere aliquid, vel non credere novimus, cum prorsus aliena sit ab istorum conspectibus oculorum, quid tam nudum, tam clarum, quid tam certum est interioribus visibus animorum? Quomodo ergo credendum non est quod corporeis oculis non videmus, cum vel credere nos, vel non credere ubi corporeos oculos adhibere non possumus, sine ulla dubitatione videamus? (De fide rerum, 1,1 ).
} 
A essa primeira provocação, os insensatos responderiam prontamente que "não há necessidade de conhecer pelos olhos do corpo estas coisas que estão no espírito, pois podemos perceber com o próprio espírito. No entanto, as coisas que dizeis para que creiamos [nelas], não as mostrais exteriormente, para que as conheçamos com o espírito, para que as vejamos com o pensamento." ${ }^{21}$ Agostinho não poupará esforços para demonstrar que "devemos crer em alguma realidade temporal que não vemos, para que mereçamos ver também aquela eterna na qual cremos" 22 , refutando aqueles que dizem 'crer somente naquilo que se vê com olhos corporais'.

Como lhe é habitual, Agostinho procede de indagação em indagação, buscando explicaçóes e exemplos na concretude das relaçóes humanas. Escutemos o próprio Agostinho:

Mas, quem quer que sejas tu que não queres crer senão no que vês, [e] vês com os olhos do corpo os corpos presentes, e com o espírito vês as tuas vontades e pensamentos - que estão no próprio espírito -, dize-me, te peço, com quais olhos vês a boa vontade do teu amigo para contigo? Pois nenhuma vontade pode ser vista com os olhos do corpo. $\mathrm{Ou}$, por acaso, vês também com o espírito o que se passa no espírito de outrem? Mas se não vês, como retribuis a boa vontade amiga, se não crês naquilo que não podes ver? Dirás que vês a boa vontade do outro pelas suas obras? Então, verás os feitos e ouvirás as palavras, mas na boa vontade do amigo, que não pode ser vista nem ouvida, crerás.

Com efeito, essa boa vontade não é uma cor ou uma figura posta diante dos olhos, não é um som ou uma cantiga que chega aos ouvidos, nem é algo de teu, sentido pela afeição do coração. Então, [só] te resta crer no que náo vês, no que náo ouves e no que não podes perceber dentro de ti, para que tua vida náo seja vazia, desprovida de amizade, e para que o amor que te foi oferecido não seja, por sua vez, por ti retribuído. Onde está, então, aquilo que dizias, que não deves crer senão naquilo que vês, ou externamente com o corpo ou internamente com o coração? ( $A$ fé nas coisas invisiveis, 2 , grifo nosso). ${ }^{23}$

\footnotetext{
${ }^{21}$ Sed, inquiunt, ista quae in animo sunt, cum possimus ipso animo cernere, non opus habemus per oculos corporis nosse: quae autem dicitis vos ut credamus, nec foris ostenditis, ut ea per oculos corporis noverimus, nec intus in animo nostro sunt, ut ea cogitando videamus. Sic ista dicunt, quasi quisquam credere iuberetur, si iam sibi praesentatum posset videre quod creditur. Ideo utique debemus credere nonnulla etiam temporalia, quae non videmus, ut aeterna etiam mereamur videre, quae credimus. ( $D e$ fide rerum, 1, 2).

${ }^{22}$ Ideo utique debemus credere nonnulla etiam temporalia, quae non videmus, ut aeterna etiam mereamur videre, quae credimus. (De fide rerum, 1, 2).

${ }^{23}$ Sed quisquis es, qui non vis credere nisi quod vides, ecce praesentia corpora corporeis oculis vides, praesentes voluntates et cogitationes tuas, quia in animo tuo sunt, ipso animo vides: dic mihi, obsecro
} 
Sem dúvida, um texto memorável. As dimensōes visível/invisível, de tal forma entrelaçadas, a ponto de cremos em um coração que não é o nosso: "Eis que do teu coração crês em um coração que não é o teu, e pões a tua fé naquilo para o qual não podes dirigir o olhar, nem da mente nem da carne." (A fé nas coisas invisiveis, 2). ${ }^{24} \mathrm{E}$ esse movimento, de coração para coração, não é uma relação simétrica, feita sob medida. Ao contrário, é um movimento ondular como a nos impulsionar para além do que é visto que, por si só, acaba por empobrecer sobremaneira a vida. Agostinho dá exemplos que ilustram esse 'movimento':

Com o teu corpo distingues a face do amigo, com o teu espírito distingues a tua fé. A fé do amigo, porém, não pode ser amada por ti, se em ti, por tua vez, não há aquela fé com a qual creres naquilo que nele não podes ver - embora o homem, porque não tem a caridade, possa enganar fingindo benevolência, escondendo a maldade; ou ainda que não pretenda prejudicar[-te], todavia, com a expectativa de obter de ti algum benefício, simule [a amizade]. (A fé nas coisas invisiveis, 2). ${ }^{25}$

Creio que todos ou muitos de nós poderíamos relatar, infelizmente, experiências dessa natureza. Por exemplo, costuma-se dizer que conhecemos os amigos nas horas dos apertos. Ao ler esse sermão de Agostinho, que toca diretamente em questóes que nos são bastante familiares, percebemos sua força vivificadora, um mergulho nas pequenas angústias e aflições de qualquer um, seja letrado, camponês, comerciante, sem maiores rodeios e retóricas vãs. Vejamos o que disse Agostinho: "Dizes, porém, que por isso crês no amigo,

te, amici tui erga te voluntatem quibus oculis vides? Nulla enim voluntas corporeis oculis videri potest. An vero etiam hoc vides animo tuo, quod in animo agitur alieno? Quod si non vides, quomodo amicali benevolentiae vicem rependis, si quod non potes videre, non credis? An forte dicturus es, alterius voluntatem per eius opera te videre? Ergo facta visurus, et verba es auditurus, de amici autem voluntate id quod videri et audiri non potest crediturus. Non enim voluntas illa color est aut figura, ut oculis ingeratur; vel sonus aut cantilena, ut auribus illabatur; aut vero tua est, ut tui cordis affectione sentiatur. Restat itaque, ut nec visa, nec audita, nec apud te intus conspecta credatur, ne tua vita deserta sine ulla amicitia relinquatur, vel impensa tibi dilectio vicissim abs te non rependatur. Ubi est ergo quod dicebas, te credere non debere, nisi quod videres aut extrinsecus corpore, aut intrinsecus corde? (De fide rerum, 1, 2).

${ }^{24}$ Ubi est ergo quod dicebas, te credere non debere, nisi quod videres aut extrinsecus corpore, aut intrinsecus corde? Ecce ex corde tuo, credis cordi non tuo; et quo nec carnis nec mentis dirigis aciem, accommodas fidem. (De fide rerum, I, 2).

${ }^{25}$ Amici faciem cernis corpore tuo, fidem tuam cernis animo tuo: amici vero non abs te amatur fides, si non in te mutuo illa sit fides, qua credas quod in illo non vides. Quamvis homo possit et fallere fingendo benevolentiam, tegendo malitiam: aut si nocere non cogitat, tamen exspectando a te aliquam commoditatem, simulat, quia caritatem non habet. (De fide rerum, 1, 3). 
cujo coração não podes ver, porque o provaste nas tuas dificuldades e vieste a saber qual sua disposiçáo para contigo nos teus apuros, quando ele não te abandonou. Por acaso pensas que devamos desejar a nossa [própria] adversidade para provar o amor do amigo para conosco?" (A fé nas coisas invisiveis, 3). ${ }^{26}$ Ou dizendo de outra maneira e com menos gentileza. Será que eu preciso ficar doente para 'ver' quem virá em meu socorro? Será que, pergunta Agostinho, "não haverá alguém feliz por um amigo certíssimo de modo que desfrute do amor manifesto pelo outro, a não ser que tenha sido infeliz na adversidade, a não ser que tenha sido atormentado pela própria dor ou temor?" ( $A$ fé nas coisas invisiveis, 3). ${ }^{27} \mathrm{E}$ isso não é de se ver à primeira vista. Só com olhos próprios da fé.

No capítulo II - Fide de rebus humanis sublata, quam horrenda confusio sequeretur - o tema se alarga e Agostinho liga um tópico a outro em suas devidas correlaçóes para demonstrar que, sem a fé, a sociedade humana sucumbiria, tamanha a confusão nos diversos níveis de relacionamentos. Agostinho se vale do último exemplo do capítulo anterior, que se refere à 'fé' que temos no amigo. Ele escreve: "Mas, certamente, para prová-lo [a amizade], não te aproximarias de teus apuros se náo acreditasses [nele]. Por isso, ao te aproximares [dele] para prová-lo/aprová-lo, crês antes de prová-lo. Como então não devemos crer no que não pode ser visto." (A fé nas coisas invisiveis, 3) ${ }^{28} \mathrm{E}$ ainda complementa: "Pois, certamente, se já que cremos nos coraçôes dos amigos quando estes ainda não foram provados, e a partir do momento que temos provas de que são bons, graças aos nossos sofrimentos, então mais do que ver a boa vontade deles para conosco cremos [nessa boa vontade]." (A fé nas coisas invisiveis, 3). ${ }^{29}$

Dessa forma fica posto que se o afeto ou amor dos amigos pode ser provado na adversidade, justamente devemos crer no que não podemos ver.

\footnotetext{
${ }^{26}$ Sed dicis, ideo te credere amico, cuius videre cor non potes, quia in tuis tentationibus eum probasti, et cuiusmodi animum erga te haberet in tuis periculis, ubi te non deseruit, cognovisti. Numquid ergo, ut amicorum probetur erga nos caritas, videtur tibi nostra optanda calamitas? (De fide rerum, 1, 3).

${ }^{27} \mathrm{Nec}$ quisquam erit ex amicis certissimis felix, nisi fuerit adversis rebus infelix: ut videlicet explorato alterius amore non fruatur, nisi suo dolore vel timore crucietur. Et quomodo in habendis veris amicis optari ea, non potius timeri, felicitas potest quam probare nisi infelicitas non potest. (De fide rerum, I, 3).

${ }^{28}$ Sed utique ut eum probes, periculis tuis nec te committeres, nisi crederes: ac per hoc cum te committis ut probes, credis antequam probes. Certe enim si rebus non visis credere non debemus, quandoquidem et nondum certius probatis amicorum cordibus credimus. (De fide rerum, II, 3).

29 "Et cum ea malis nostris bona probaverimus, etiam tunc eorum erga nos benevolentiam credimus potius, quam videmus: nisi quia tanta fides est, ut non incongruenter quibusdam oculis eius nos iudicemus videre quod credimus; cum propterea credere debeamus, quia videre non possumus. ( $D e$ fide rerum, II, 3).
} 
Dessa prova, Agostinho retira uma outra prova, por assim dizer, para confirmar sua proposição acerca da enorme confusão, pertubatio - e já as temos demais -, se a fé deixasse de ser esse cimento, essa liga que nos inscreve num universo que é também moral: "Se essa fé fosse subtraída das relaçôes humanas, quem não daria atenção a tal perturbação [que haveria] nelas e a tão horrendo caos que se seguiria? Quem seria amado com mútua caridade por alguém, quando o próprio amor é invisível e se não devo crer no que não vejo?" ( $A$ fé nas coisas invisiveis, 4).$^{30} \mathrm{~A}$ resposta é óbvia. Sem amor recíproco não há amizade: "Assim, toda a amizade pereceria, pois esta não é senão um amor recíproco. Afinal, o que se poderia receber de amor de quem quer que seja, se não crê que nada dele seja oferecido?" (A fé nas coisas invisiveis, 4$){ }^{31}$

Em sua resposta Agostinho nos lembra do amor dos pais para com os filhos e dos filhos para com os pais e de tantos outros vínculos amorosos. Irmãos, genros, vínculos de parentesco ou mesmo a simples afinidade. O que pesaria, por exemplo, na decisão de gerar filhos, se se estimasse alcançar apenas açóes que podem ser vistas e valoradas, pois nada garantiria que esses filhos viessem a amar os pais. Se o amor vingasse apenas no terreno da obrigação, da retribuição contabilizada, seria troca de interesses, de favores e demais penduricalhos do modo utilitarista de viver. Não seria amor e, essa cautela com aquilo que não nos é comprovado é odiosa: "[É] odiosa essa cautela com a qual não cremos que somos amados, por não vermos o amor de quem nos ama e não retribuirmos, por nossa vez, àqueles a quem considerarmos não ter que retribuir." (A fé nas coisas invisiveis, 4$).^{32}$

Como se vê, o texto agostiniano prima pelo tom afinado com o nosso cotidiano, de fazer soar o que parece posto e disposto no lugar habitual. Em tempos de pseudoamizades, de precificação das relaçóes sociais, contadas pelo número de likes ou deslikes, vale prestar atenção em Agostinho: "Se, entáo, não crermos no que não podemos ver, a própria sociedade humana perecendo de concórdia, não se sustentará. [Assim]. Quanto maior fé é preciso colocar nas coisas divinas - embora não as possamos ver -, às quais não aderir seria violar

\footnotetext{
${ }^{30}$ Tota itaque peribit amicitia, quia non nisi mutuo amore constat. Quid enim eius poterit ab aliquo recipere, si nihil eius creditum fuerit exhiberi? (De fide rerum, II, 4).

${ }^{31}$ De fide rerum, II, 4.

32 Porro si non ingeniosa, sed odiosa est ista cautela, ubi nos amari non credimus, quod amorem amantium non videmus, vicemque non rependimus, quibus eam nos debere mutuam non putamus. (De fide rerum, II, 4).
} 
não a amizade de um homem qualquer, mas a própria suprema religião, o que resulta em profunda infelicidade." (A fé nas coisas invisiveis, 4). ${ }^{33}$

Se tomamos esse pressuposto no que toca às relaçóes pedagógicas, por exemplo, poderíamos decretar o fim das escolas. Entre professores e alunos a primeiríssima relação é de confiança, vale dizer de fé. No primeiro dia de aula, por exemplo, o professor não precisa pedir para que os alunos acreditem nele. Porque essa 'fé no que não vejo' é aposta numa relação amorosa, cujos laços, muitas vezes, não se desfazem. E que começou por um ato de fé...

O mesmo valeria para a crença de que nossos pais são, de verdade, nossos pais. Só sabemos quem são nossos pais porque eles nos contaram. E acreditamos. Ainda que a tecnologia mais refinada nos forneça provas científicas, mediante a investigação do DNA, ainda assim é preciso crer que não houve manipulaçáo, erro de leitura, desvio, troca de materiais etc. Parece então que o teste agostiniano de DNA é mais crível e, ainda, pode se estender aos vários campos da vida em sociedade. Vejamos a confirmação:

\begin{abstract}
Abstenho-me de dizer em quantas coisas acreditam - sejam da tradição e da história ou a respeito de lugares onde nunca estiveram - aqueles que nos criticam pelo fato de crermos naquilo que náo vemos, e náo digam: "Não cremos porque não vimos!" Pois, se dissessem isso, seriam obrigados a dizer-se incertos com relaçấo aos seus genitores, pois nesse caso acreditariam no que foi contado por outros, já que não é possível mostrar aquilo que já passou, e nada recordando daquele tempo [de seu nascimento], acreditaram, todavia, sem dúvida alguma no que lhes foi dito. Se assim não fosse, faltar-se-ia em ímpio desrespeito para com os genitores, enquanto se tenta como que evitar a temeridade de crer no que não podemos ver. (A fé nas coisas invisiveis, 4$).{ }^{34}$
\end{abstract}

Desse modo, do que parece mais óbvio, Agostinho é capaz de nos fazer pensar e ampliar o que chamamos de 'horizonte de visibilidades'. Muitas vezes nosso horizonte fica embaçado, tal como vidro de automóveis em dias

\footnotetext{
${ }^{33}$ Usque adeo res humanae perturbantur, si quod non videmus, non credamus. ut omnino funditus evertantur, si nullas credamus hominum voluntates, quas utique videre non possumus. (De fide rerum, II, 4).

${ }^{34}$ Omitto dicere quam multa isti, qui nos reprehendunt, quia credimus quae non videmus, credant famae et historiae, vel de locis ubi ipsi non fuerunt; nec dicant: Non credimus, quia non vidimus. Quoniam si hoc dicant, coguntur fateri incertos sibi esse parentes suos: quia et hinc aliis narrantibus, nec tamen quia iam praeteritum est id ostendere valentibus, crediderunt, nullum retinentes illius temporis sensum, et tamen aliis inde loquentibus adhibentes sine ulla dubitatione consensum; quod nisi fiat, incurratur necesse est adversus parentes infidelis impietas, dum quasi vitatur in his quae videre non possumus credendi temeritas. (De fide rerum, II, 4).
} 
de neblina. A inteligência da fé seria, dessa forma, exercício para desembaciar nossas vidraças, que são muitas.

Já no capítulo terceiro - Indicia quae confirmant fidem. Prophetiae de eclessia impletae - Agostinho fará a exposição de motivos para crer, a partir da comprovação do cumprimento das profecias. Sem perder o tema principal, Agostinho toma o lugar de interlocutor e se serve da sua objeção: "Mas, dirás, 'a benevolência de um homem amigo para comigo, ainda que eu não a possa ver, posso, todavia, rastreá-la por muitos indícios'. Vós, porém, quereis que acreditemos naquilo que não foi visto [e] do qual náo podeis mostrar nenhum indício." (A fé nas coisas visiveis, 5). ${ }^{35}$

A resposta não poderia ser outra senão aquela 'que não se deve não crer em tudo que não se pode ver', referindo-se às profecias que, previstas e realizadas, são evidentes à razão humana e que contrariam a tese que 'não devemos crer nas coisas que não vemos', pois, rebate Agostinho: "Muitos se enganam, porém, aqueles que consideram que cremos em Cristo sem evidência alguma acerca de Cristo. De fato, quais indícios são mais claros do que aqueles que, preditos e realizados, agora vemos?" (A fé nas coisas invisiveis, 5). ${ }^{36}$

Agostinho, cuidadoso leitor e intérprete dos textos da Escritura, confirma sua argumentação, ao longo desse capítulo, numa longa explicação em que se apoia no livro do Gênesis (Gn 22,18), em Isaias (Is 7-14) e nos Salmos (Sl 45). Lembremo-nos de que se trata de um sermão e, portanto, pode e deve fundamentar-se na doutrina cristã.

No capítulo seguinte - Ad credenda quae non vidimus movere debent quae nunc impleta conspicimus - também será esse o seu procedimento hermenêutico. Frequentemente, nos textos de Agostinho, em seus diversos gêneros, encontramos essa combinação filosófico-teológica que, aos olhos dos modernos, parece invalidar o posto da supremacia da razão na investigação das coisas humanas e divinas. Agostinho, como homem do seu tempo, foi capaz de fazer aproximaçóes, confrontaçóes e mesmo entrelaçar saberes distintos, sem

\footnotetext{
${ }^{35}$ Sed amici hominis, inquies, erga me benevolentiam quamquam videre non possum, multis tamen indiciis indagare possum: vos autem quae vultis ut non visa credamus, nullis indiciis potestis ostendere. Interim non parum est, quod fateris quorumdam indiciorum perspicuitate res aliquas, etiam quae non videntur, credi oportere: etiam sic enim constat, non omnia quae non videntur, non esse credend. (De fide rerum, III, 5).

${ }^{36}$ Multum autem falluntur qui putant nos sine ullis de Christo indiciis credere in Christum. Nam quae sunt indicia clariora, quam ea quae nunc videmus praedicta et impleta? Proinde qui putatis nulla esse indicia cur de Christo credere debeatis quae non vidistis, attendite quae videtis. (De fide rerum, III, 5).
} 
prejuízos. Hoje essa relação entre fronteiras dos vários saberes seria chamada simplesmente de interdisciplinaridade.

E dessa forma, no capítulo V - Praesentium exhibitio astruit fidem praeteritorum et futurorum - Agostinho retoma o fio da meada reafirmando que a visão do presente é motivo da fé tanto no passado quanto no futuro. Sabemos de sua agudeza de espírito e genialidade ao tratar a questão do tempo, em Confissóes, especialmente no livro XI, ao propor o conceito de tempo como distentio anima. ${ }^{37}$

Nesse viés temporalizante, em que estamos todos como arco tensionados, Agostinho procurará ampliar e aclarar ainda mais o que é mesmo essa fé sobre as coisas que não vemos, focalizando especificamente a Igreja como realidade histórica e trans-histórica. Assim ele escreve: "Já que através de indícios, que vemos, cremos na intenção, que não vemos, dos amigos, assim [é também com] a Igreja, que agora se vê: ela é indício das coisas passadas e é prenunciadora das coisas futuras, [isto é,] de tudo que se vê apontado em seus escritos - onde ela mesma é prenunciada." "Pois as coisas passadas, que já não se podem ver, e as coisas futuras, que ainda não se podem ver, e as coisas do presente, que agora podem ser vistas, eram todas porvir quando foram prenunciadas, e nenhuma delas pudera ser vista naquele momento." ( $A$ fé nas coisas invisiveis, 8). ${ }^{38}$

Ainda nesse trecho vê-se o bom jogo dialético: por que não deveríamos crer nas coisas passadas e futuras que não vemos, tendo a sua comprovação no presente que vemos e, lendo - ou ouvindo - nos textos sagrados que os acontecimentos passados, presentes e futuros foram anunciados antes mesmo de acontecer? A não ser, provoca Agostinho, que os "homens infiéis julguem que [todas] essas coisas foram escritas pelos cristãos, de modo que [todas] elas, nas quais já acreditavam ou que conheciam, tivessem um peso de autoridade maior, considerando que foram prometidas antes que acontecessem". ( $A$ fé nas coisas invisiveis, 8$){ }^{39}$

\footnotetext{
${ }^{37} \mathrm{Cf}$. Confissôes: Inde mihi visum est nihil esse aliud tempus quam distentionem: sed cuius rei, nescio, et mirum, si non ipsius animi. (Livro XI, xxvi, 33).

${ }^{38}$ Sed quemadmodum voluntates amicorum quae non videntur, creduntur per indicia quae videntur; sic Ecclesia quae nunc videtur, omnium quae non videntur, sed in eis litteris ubi et ipsa est praedicta monstrantur, et index est praeteritorum, et praenuntia futurorum. (De fide rerum, $\mathrm{V}, 8$ ).

${ }^{39}$ Nisi forte arbitrantur homines infideles a Christianis illa esse conscripta, ut ista quae iam credebant maius haberent pondus auctoritatis, si antequam venirent, putarentur esse promissa. (De fide rerum, V, 8).
} 
Desse modo Agostinho resguarda a dimensão trans-histórica da Igreja conjugando o passado (o que não é mais, mas eu creio), o presente (o que é e eu não o vejo em sua totalidade) e o futuro (que ainda não é, mas que eu espero). Se espero creio. Se não acreditasse não esperaria.

Dando continuidade à argumentação em defesa da força crível que se extrai do conhecimento dos livros sagrados, Agostinho reforça a orientaçáo para que se leiam e investiguem com ele os livros do Velho Testamento nessa chamada crítico-analítica que abre o capítulo VI: Iudaeorum codices fidei nostrae astipulantur. Iudaeorum secta quare non prorsus deleta (Os livros dos judeus provam nossa fé. Porque não foi exterminada a seita dos judeus). Não se dispensa a leitura de toda a página para acompanhar esse exercício hermenêutico. Da história do povo judeu, de sua dispersão pelo mundo, chegam para os cristâos sinais visíveis da fé. Tudo que lhes passou, já anunciado, nem sempre foi compreendido. Interessante que Agostinho usa a expressão 'falta de inteligência' e não falta de fé para expressar o motivo pelo qual muitas pessoas, 'cegadas pelo ódio', não são capazes de compreender o que foi anunciado.

Também é importante sublinhar a expressão 'olhos cegados' (oculis obscuratis). Em muitas de suas obras, a metáfora da saúde dos olhos é recorrente. Se com olhos cegados, de fato, não podemos ver nem o que é visível, quanto mais o invisível. Claro, olhos cegados náo por alguma deficiência física, mas pelas deficiências ideológicas, miopizantes. Agostinho faz um pedido peremptório para que procuremos cuidar da saúde dos olhos:

Se nossos inimigos suspeitam disso, que examinem os escritos dos judeus. Neles, lerão essas coisas que lembramos que foram preditas sobre Cristo, no qual cremos, e sobre a Igreja, que vemos, desde o fatigoso início da [propagação da] fé até a beatitude eterna do reino; e [lerão] muitas outras mais, quase inumeráveis, que não mencionamos. Mas, lendo-as, não se admirem com o náo entendimento dessas coisas por aqueles que possuem tais livros devido às trevas da inimizade. De fato, foi predito pelos mesmos profetas que eles não entenderiam. Como tudo mais, era preciso que isso se cumprisse, e sofressem a pena merecida segundo um secreto, mas justo, juízo de Deus. É certo, Ele - a quem crucificaram e a quem deram fel e vinagre -, ainda que pendendo no lenho por aqueles que seriam conduzidos das trevas à luz, disse: "Pai, perdoa-lhes, pois não sabem o que fazem. (A fé nas coisas invisiveis, 9). ${ }^{40}$

\footnotetext{
${ }^{40}$ Quod si suspicantur inimicorum nostrorum Iudaeorum codices perscrutentur. Ibi legant ista quae commemoravimus, praenuntiata de Christo in quem credimus, et Ecclesia quam cernimus ab initio laborioso fidei usque ad sempiternam beatitudinem regni. Sed cum legunt, non mirentur quod ista illi quorum codices sunt, propter inimicitiarum tenebras non intellegunt. Nam eos non intellecturos
} 


\section{Após um 'sermão' dentro do sermão, Agostinho buscará mais exemplos que comprovem a maravilhosa conversão do mundo à fé de Cristo como por exemplo:}

Em todo caso, mesmo se não tivéssemos tido testemunhos proféticos precedentes sobre o Cristo e a Igreja, quem náo deveria sentir-se levado a crer que a claridade divina repentinamente tenha iluminado o gênero humano quando vemos os falsos deuses serem abandonados e suas estátuas quebradas, seus templos demolidos ou transformados para outro uso, tantos ritos vãos extirpados da tão firme consuetude humana e um único e verdadeiro Deus ser invocado por todos? (A fé nas coisas invisiveis, 10). ${ }^{41}$

Esse é o tom, interrogativo, do capítulo VII - Totius mundi fides in Christum Mirabiliter conciliata - que retratará com muita fidelidade aquela paisagem histórica que Agostinho viu de perto e que lhe instiga a perguntar pelo responsável por toda aquela revolução. Quem teria colocado o mundo de 'ponta-cabeça'?

E isso aconteceu por causa de um homem que pelos homens foi zombado, capturado, acorrentado, flagelado, esbofeteado, ridicularizado, crucificado e morto. Ele escolheu aqueles discípulos incultos e inexperientes, pescadores e publicanos - pelos quais difundiria seus ensinamentos - que anunciaram sua ressureição e [sua] ascensão ao céu, dizendo tê-lo visto, e, cheios do Espírito Santo, proclamaram o Evangelho em todas as línguas, que nunca aprenderam. Daqueles que os escutaram, uma parte acreditou; a parte que não acreditou opôs-se ferozmente aos pregadores. Assim, os fiéis combateram pela verdade até a morte, não repagando o mal, mas sofrendo-o, venceram - não matando, mas morrendo." ( $A$ fé nas coisas invisiveis, 10). ${ }^{42}$

ab eisdem Prophetis ante praedictum est: quod ut cetera oportebat impleri, et occulto iustoque iudicio Dei meritis eorum poenam debitam reddi. Ille quippe quem crucifixerunt, et cui fel et acetum dederunt, quamvis in ligno pendens, propter eos quos fuerat in lucem de tenebris educturus, dixerit Patri: Ignosce illis, quia nesciunt quid faciun. (De fide rerum, VI, 9).

${ }^{41}$ Quamquam etiam si de Christo et Ecclesia testimonia nulla praecederent, quem non movere deberet ut crederet, repente illuxisse divinam humano generi claritatem, quando videmus relictis diis falsis, et eorum confractis usquequaque simulacris, templis subversis, sive in usus alios commutatis, atque ab humana veternosissima consuetudine tot vanis ritibus exstirpatis, unum verum Deum ab omnibus invocari? (De fide rerum, VII, 10).

${ }^{42}$ Et hoc esse factum per unum hominem ab hominibus illusum, comprehensum, vinctum, flagellatum, expalmatum, exprobratum, crucifixum, occisum: discipulis eius, quos idiotas, et imperitos, et piscatores, et publicanos, per quos eius magisterium commendaretur, elegit, annuntiantibus eius resurrectionem, ascensionem, quam se vidisse dixerunt, et impleti Spiritu Sancto, hoc Evangelium linguis omnibus, quas non didicerant, sonuerunt. Quos qui audierunt, partim crediderunt, partim non credentes praedicantibus ferociter restiterunt. Ita fidelibus usque ad mortem pro veritate, non 
Agostinho entendia, nessa perspectiva, que se se permitiu a propagação de seitas contrárias à fé cristá, seria para dessa contradição - entre Evangelho e seitas impiedosas (secta perversa) - comprovar a doutrina verdadeira. Insiste Agostinho: "Ainda que nenhuma das tais coisas futuras tivesse sido predita pelos profetas, como aquele crucifixo teria podido realizar tanto, a não ser que Deus tivesse assumido a carne humana?” (A fé nas coisas invisiveis, 10). ${ }^{43}$

Dito tudo isso, o bom orador caminha para a conclusão. E qual seria, nesse caso? A única possível. Exortar seus ouvintes a permanecerem na fé. Imaginem o velho bispo, incansável nas contendas sem fim, dizendo, no capítulo VIII - Ad fidei immobilem observantiam cohortatio: "Vós, porém, caríssimos, que possuís essa fé ou que agora começastes a possuí-la como [realidade] nova, nutri-a, e que ela cresça em vós." (A fé nas coisas invisiveis, 11). ${ }^{44}$

Parece estar aí mais uma admoestação do que um sermão, do professor e do pregador, pois lhes diz: "Como se cumpriu o que muito [tempo] antes foi predito, assim se cumprirão as promessas sempiternas. Que não vos enganem nem os infrutíferos pagãos, nem falsos judeus, nem os maus cristãos [que há] dentro da própria Igreja, que são inimigos tâo mais nocivos quanto mais íntimos." (A fé nas coisas invisiveis, 11). ${ }^{45}$

Agostinho finalizará esse texto citando o versículo II do Cântico dos cânticos, "como um lírio entre espinhos, assim é minha amada em meio a outras moças" (Ct, 2), e com uma advertência profética de Mateus, para que não restasse nenhuma dúvida, "quem tem ouvidos ouça" (Mt 13,9).

E nós, o que temos para ouvir? Agostinho lembra ainda do evangelista para dizer que quando a rede, lançada ao mar, reúne peixes de todos os dias e, trazida à praia, "separe-se dos maus peixes com o coração, não com o corpo;

mala rependendo, sed perpetiendo certantibus, nec occidendo, sed moriendo vincentibus. (De fide rerum, VII, 10).

${ }^{43}$ Quando tantum crucifixus ille potuisset, nisi Deus hominem suscepisset, etiamsi nulla per Prophetas futura talia praedixisset? (De fide rerum, VII, 10).

${ }^{44}$ Vos autem, carissimi qui hanc fidem habetis vel qui nunc novam habere coepistis, nutriatur et crescat in vobis. (De fide rerum, VIII, 11).

45 Sicut enim venerunt temporalia tanto ante praedicta, venient et sempiterna promissa. Nec vos decipiant vel vani Pagani, vel falsi Iudaei, vel fallaces haeretici, nec non in ipsa Catholica mali Christiani, tanto nocentiores, quanto interiores inimici. (De fidem rerum, VIII, 11). 
mudando os maus costumes, não rasgando a santa rede" ( $A$ fé nas coisas invisiveis, 10$)^{46}$.

E como proceder para empreender essa tarefa que é de uma vida inteira? Deixar de lançar a rede? Ou apenas jogar fora os peixes maus? Provavelmente não. Talvez mudando os hábitos, não os do corpo, mas os do coração. Mas ainda assim estariam os bons misturados aos maus? Ou estariam separados? Seria, afinal, o mundo visível um maniqueísmo aplicado? Creio que, tratandose de um sermão, Agostinho teria cuidado para evitar ambiguidades dessa natureza. Mas a oralidade tem esses obstáculos, ao passo que a palavra escrita permite fazer os reparos. O sermão termina com o versículo de Mateus, "para que os justos, agora se veem misturados aos injustos, quando na praia começar a separação, recebam não a pena, mas a vida eterna” (Mt 13,47-49) que, se tomado fora de contexto, poderia dar margem a interpretaçóes que comprometem o pensamento do autor. Nesse caso, precisaríamos voltar à Cidade de Deus, para evitar certos equívocos, tais como atribuir a Agostinho um dualismo inflexível e uma liberdade comprometida por uma predestinação.

Por ora o importante é compreender que o autor do sermão é aquele Agostinho que se lançou na busca árdua e espinhosa de mostrar aos seus contemporâneos, pelo exercício da palavra, que a fé tem olhos próprios. No século XXI, parece ser uma empreitada mais difícil ainda. Náo porque nos faltem argumentos. Esses estão nesse sermão, estão nos incríveis emaranhados e redes da cibercultura. Por primeiro, precisaríamos não nos acontentarmos com os olhos da razáo, para transver o mundo, como escreveu o poeta Manoel de Barros $^{47}$. Nesse sentido, a razão vê, mas a fé transvê com seus próprios olhos.

\footnotetext{
${ }^{46}$ Et dum sagena quae missa est in mare, et congregat omnia genera piscium, sicut sanctum loquitur Evangelium, trahitur ad litus, id est, ad saeculi finem secernat se a piscibus malis, corde, non corpore; mores malos mutando, non retia sancta rumpendo: ne qui nunc probati reprobis videntur esse permixti, non vitam, sed poenam reperiant sempiternam, cum coeperint in littore separari. (De fide rerum, VIII, 11).

47 "A expressão reta não sonha. / Não use o traço acostumado. / A força de um artista vem das suas derrotas. / Só a alma atormentada pode trazer para a voz um formato de pássaro. / Arte náo tem pensa: / O olho vê, a lembrança revê, e a imaginação transvê. / É preciso transver o mundo." Disponível em: <https://www.academia.edu/ 11319215/Poesia_Completa_Manoel_de_Barros>.
} 
CONTALDO, S. M. Augustine: faith has its own eyes. Trans/Form/Ação, Marília, v. 42, p. 115-134, 2019. Ediçáo Especial.

\begin{abstract}
This article is a commentary on a text of St Augustine entitled De fide rerum quae non videntur, which is a sermon motivated by the misconceptions or even mistakes of those who do not profess the Christian faith. The text was probably written between 420-425 A.D., a time conducive to strengthening of faith in invisible things, given the historical horizon that heralded the decline of the Roman Empire. In the composition of the text, in line with the proper style of a sermon, there are eight brief parts. Without losing cohesion with regard to the main theme, Augustine concludes that faith has its own eyes capable of seeing - and allowing us to believe in - invisible things.
\end{abstract}

KEYwORDs: St. Augustine. Faith. Sermon. Christian religion. Interiority.

\title{
REFERÊNCIAS
}

LAUAND, J. P. Dois sermóes sobre Agostinho. In: (org.) Cultura e educação na Idade Média. São Paulo: Martins Fontes, 1998. Disponível em: <http://www.hottopos. com/mp5/ agostinho.htm>. Acesso em: 25 jun. 2018.

SAN AGUSTIN. De fide rerum quae non videntur. Madrid: Biblioteca de Autores Cristianos, 1958. Tomo IV, p. 794-817.

SANT'AGOSTINO. AugustinusHipponense. Opera Omnia. Disponível em: <http://www. augustinus.it/>. Acesso em: 20 out. 2018.

SANTO AGOSTINHO. A fé nas coisas invisiveis. São Paulo: Paulus, 2017. p. 297-314. (Patrística).

SANTO AGOSTINHO. Confissóes. Lisboa: Centro de Literatura e Cultura Portuguesa e Brasileira; Imprensa Nacional; Casa da Moeda, 2000.

TRAPÈ, A. Agostinho.o homem, o pastor, o místico. São Paulo: Scripta Publicações, 2019.

Recebido: 30/12/2019

Aceito: 30/12/2019 
CONTALDO, S. M. 